ROBERT E. HALL

Stanford University

\title{
In Honor of William Brainard and George Perry
}

The Brookings Papers on ECONOMiC ACTIVITY is a unique and amazing institution, created by three visionaries, two of whom we thank and appreciate in this volume, George Perry and William Brainard. We should not, however, forget the founding contributions of Arthur Okun, who died in 1980 , even though many readers know them only from the classic Brookings Papers of the 1970s, still full of wisdom.

The Brookings Papers was much more unique at its inception in 1970 than it is today, because it has inspired imitation and because Okun and Perry were the first to understand the value of a field-oriented, ongoing, academic conference series. In the 1960s there were no conference series in economic specialties. One went to the annual American Economic Association meetings and the Econometric Society meetings and to department seminars, but nothing else. How did we survive? The fixtures of the macroeconomics conference circuit all started later: the CarnegieRochester series in 1973; the National Bureau of Economic Research's economic fluctuations program and its International Seminar on Macroeconomics and Summer Institute in 1978; the NBER Macroeconomics Annual in 1986 (a self-conscious copy of the Brookings Papers, I can say from firsthand knowledge); and the Minnesota Workshop in Macroeconomic Theory in 1990.

The world was different in 1970, when the Brookings Panel first met. The Brookings special room rate at the Dupont Plaza for the first meeting was $\$ 14$ a night. Central cities, including the Dupont Circle area of Washington, seemed doomed. For the first decade of the Panel's existence, we would not have dreamed of crossing the center of the circle 
after 6 p.m., and we could have bought a spectacular house in Kalorama for $\$ 25,000$.

I think some people feel that the Brookings Papers missed something in that two prominent developments in macroeconomics over the period of its existence-the rational expectations revolution and the simple generalequilibrium real business cycle model—did not figure prominently in the Panel's discussions. Or, to be more candid, they were more often criticized than advanced at the Panel. With respect to rational expectations, the editors did try to bring it within the Panel's ambit. Thomas Sargent, a leading proponent, was a member of the Panel in 1973 and wrote a significant Brookings Paper, ${ }^{1}$ and Rudiger Dornbusch, who in 1976 became an instant star when he explained that rational expectations resulted in the overshooting of exchange rates, ${ }^{2}$ was active here for many years. It did not take long for the Panel to follow the macroeconomics profession in absorbing rational expectations into its daily thinking.

The Brookings Papers' hostility to the real business cycle model and its many progeny, the dynamic stochastic general-equilibrium models, is easier to explain and reflects well on the editors. When the panel was launched, big econometric models reigned over macroeconomics. The Brookings Institution had lent its name to a huge effort to produce one such model. But a strict founding principle of the Brookings Panel was no big models, and it would be hard to exaggerate how important this was for the intellectual contribution of the Brookings Papers. Big models were a dead end. I do not personally think that the smaller general-equilibrium models are a dead end, but it was an easy and understandable transition from hostility to the big models to hostility to the smaller ones when they sprang up from Minnesota. From the start the Brookings Papers was about sectors, equations, and phenomena, and not about general equilibrium. I think this was and is a great strength.

In preparing these remarks, I went through the tables of contents of the Brookings Papers for its entire history-three issues a year in the first few years and two issues a year ever since, not counting the splinter publication, the Brookings Papers on Microeconomic Activity, which ran from 1989 to 1998 . The two main conclusions I reach from my survey are the

1. Sargent (1973).

2. Dornbusch (1976). 
following: first, that the Brookings Papers has published a considerable number of papers that changed the direction of thinking in many different branches of macroeconomics; and second, that the Brookings Papers remains unique in its ability to recruit top people in the field to write original scholarly papers about current macroeconomic events.

Let me take you on a quick tour of some of the Brookings Papers' hits. This tour will not be very systematic and certainly not fair. I made a list of the papers that I thought, using lots of hindsight, had the greatest merit, and then I looked at the citation counts for those papers in Google Scholar. I am not a great believer in citation counts, but it seemed the best way to avoid further contaminating the process with my own prejudices.

The process found twenty-nine papers with more than 200 cites each. The two earliest included Lawrence Summers as either co-author or author: the 1979 paper by Kim Clark and Summers on unemployment and the 1981 paper by Summers alone on the $q$ theory of investment. ${ }^{3}$ Both are squarely in the Brookings Papers mode-one about a current phenomenon and the other about an equation.

The first paper on my list to break 300 citations was the one by Laurence Ball, Gregory Mankiw, and David Romer on new Keynesian economics, in $1988 .{ }^{4}$ That paper perhaps came dangerously close to a general-equilibrium approach, but it was simple and informative.

The Brookings Papers' first megahit, and a foundational work on the investment equation, was the paper by Steven Fazzari, Glenn Hubbard, and Bruce Petersen, also in 1988, with 1,543 cites and still counting. ${ }^{5}$ The panel's devotion to sectors and equations really paid off here.

Olivier Blanchard and Peter Diamond scored well twice with key papers on labor dynamics, once in 1989 and again in $1990 .{ }^{6}$ Blanchard teamed up with Lawrence Katz in 1992 to write a blockbuster on adjustment across regional labor markets, ${ }^{7}$ exposing some puzzles that are still under active discussion.

Robert Barro-hardly the prototypical Brookings Papers contributorco-wrote a paper with Xavier Sala-i-Martin in 1991 on the topic of growth

3. Clark and Summers (1979); Summers (1981).

4. Ball, Mankiw, and Romer (1988).

5. Fazzari, Hubbard, and Petersen (1988).

6. Blanchard and Diamond $(1989,1990)$.

7. Blanchard and Katz (1992). 
convergence between developed and developing economies. ${ }^{8}$ This was a hot area in macroeconomics at that time.

The tradition of actually paying attention to current events had a dramatic payoff for the Brookings Papers after the fall of the Soviet Union. The most heavily cited paper on my list, by Jeffrey Sachs and Andrew Warner on economic reform and integration, appeared in the twenty-fifth anniversary volume in 1995, ${ }^{9}$ following an influential Brookings Paper by Maxim Boycko, Andrei Shleifer, and Robert Vishny about privatization in Russia, published in 1993. ${ }^{10}$ When attention shifted to financial crises later in the 1990s, so did the Panel, with heavily cited papers by Sachs, Aaron Tornell, and Andrés Velasco and later by Steven Radelet and Sachs. ${ }^{11}$

Inflation and productivity, two phenomena of constant and intense interest to the panel, were the subject of papers too numerous to list. Notwithstanding that the price level has risen by a factor of 5 since the Panel's first meeting, by far the most frequently cited paper on the subject was that by George Akerlof, William Dickens, and Perry on the macroeconomics of low inflation. ${ }^{12}$

The editors of the Brookings Papers-Perry and Brainard since 1980have an enormous amount to be proud of. They brought together a diverse group of macroeconomists, got them to think about current events when the existing payoffs to academics favored longer-run thinking, and got them to focus on phenomena, puzzles, sectors, and equations rather than dissipating their resources on general-equilibrium models, big or little. The result was some of the most important and lasting papers in macroeconomics and in international economics. Truly a job well done.

\section{References}

Akerlof, George A., William T. Dickens, and George L. Perry. 1996. "The Macroeconomics of Low Inflation." BPEA, no. 1: 1-59.

Ball, Laurence, N. Gregory Mankiw, and David Romer. 1988. "The New Keynesian Economics and the Output-Inflation Trade-off." BPEA, no. 1: 1-65.

8. Barro and Sala-i-Martin (1991).

9. Sachs and Warner (1995).

10. Boycko, Shleifer, and Vishny (1993).

11. Sachs, Tornell, and Velasco (1996); Radelet and Sachs (1998).

12. Akerlof, Dickens, and Perry (1996). 
Barro, Robert J., and Xavier Sala-i-Martin. 1991. "Convergence across States and Regions." BPEA, no. 1: 107-58.

Blanchard, Olivier Jean, and Peter Diamond. 1989. "The Beveridge Curve." $B P E A$, no. 1: 1-60.

1990. "The Cyclical Behavior of the Gross Flows of U.S. Workers." $B P E A$, no. 2: 85-143.

Blanchard, Olivier Jean, and Lawrence Katz. 1992. "Regional Evolutions." BPEA, no. 1: 1-60.

Boycko, Maxim, Andrei Shleifer, and Robert W. Vishny. 1993. "Privatizing Russia." BPEA, no, 1: 139-92.

Clark, Kim B., and Lawrence H. Summers. 1979. "Labor Market Dynamics and Unemployment: A Reconsideration.” BPEA, no. 1: 13-60.

Dornbusch, Rudiger. 1976. "Expectations and Exchange Rate Dynamics.” Journal of Political Economy 84, no. 6: 1161-76.

Fazzari, Steven M., R. Glenn Hubbard, and Bruce C. Petersen. 1988. "Financing Constraints and Corporate Investment." BPEA, no. 2: 141-95.

Radelet, Steven, and Jeffrey D. Sachs. 1998. "The East-Asian Financial Crisis: Diagnosis, Remedies, Prospects." BPEA, no. 1: 1-90.

Sachs, Jeffrey D., and Andrew Warner. 1995. "Economic Reform and the Process of Global Integration.” BPEA, no. 1: 1-95.

Sachs, Jeffrey D., Aaron Tornell, and Andrés Velasco. 1996. "Financial Crises in. Emerging Markets: The Lessons from 1995.” BPEA, no. 1: 147-215.

Sargent, Thomas J. 1973. "Rational Expectations, the Real Rate of Interest, and the Natural Rate of Unemployment." BPEA, no. 2: 429-72.

Summers, Lawrence H. 1981. "Taxation and Corporate Investment: A $q$-Theory Approach.” BPEA, no. 1: 67-127. 
